\title{
Engagement as a Brand Position in the Higher Education Marketplace
}

Received (in revised form): June 14, 2007

\section{Jay Blanton}

is Executive Director for public relations and marketing at the University of Kentucky (UK). He is a graduate student in the UK Department of Educational Policy Studies and Evaluation.

\begin{abstract}
The purpose of this paper is to examine public engagement as a branding and public relations strategy at colleges and universities. Specifically, this paper posits the idea that engagement efforts require a focused and, if possible, centralized approach on the part of colleges and universities. Successful branding and marketing of engagement efforts require a similar approach-an alignment, if not centralization, of resources within the campus, led by the institution's president and focused on an integrated strategic message backed by research. As a result, this paper-through a case study of one large public university's efforts to brand engagement-suggests that successful branding and engagement are inter-related and, to a large, degree interdependent.

International Journal of Educational Advancement (2007) 7, 143-154. doi:10.1057/palgrave.ijea.2150056
\end{abstract}

\footnotetext{
Author's Contact Address:

Jay Blanton

UK Public Relations

University of Kentucky

102 Mathews Building

Lexington, KY 40506-0047, USA

Phone: +18592576605

Email: jdblan3@email.uky.edu
}

Keywords:

branding, public engagement, marketing

\section{Introduction}

University of Kentucky President Lee

T. Todd, Jr. knew his idea of a

"business plan" was picking up steam in the public marketplace, ironically enough, when he went shopping just before Christmas in 2005.

Todd said that in three different stores, in different parts of Lexington where the University of Kentucky (UK) is located, business owners came up to him and started talking about UK's “Top 20 Business Plan," an inch-thick document that outlines a multi-billion funding request by the university as part of its plan to become a top-tier public research institution by the year 2020. "It struck a nerve in the local community and, culturally, what I see now is that people on campus aren't nearly as cynical (about the idea)" as they were after a few years of state budget cuts when "(I continued) talking about this Top 20 thing" (Todd, 2007, personal communication, 14 March).

The sudden surge in public interest was the result, in part, of a lengthy article about the business plan that 
appeared in Lexington's local paper,

The Lexington Herald-Leader.

University officials made the decision to give the paper an exclusive about the release of the plan, hoping that it would provide more prominent coverage as a result and also because faculty and staff read the paper closely (Todd, 2007, personal communication, 14 March). Moreover, the article appeared right before the start of a legislative session in January 2006, in which Todd and the university would ask for the first cash infusion of appropriations to kick-start the plan (Blackford, 2005).

The article, though, was the result of more than 18 months of work on the business plan. That included not only the formulation of a financial planning document, which essentially is the thrust of the business plan. But it also included the creation of a targeted communications plan that, in some important ways, resembled messaging for a political campaign: baseline research of likely supporters through a statewide survey; a statewide bus tour that touted the need for a top public university and the financial support to drive it there; and earned media and advertising efforts that largely targeted those most likely to influence legislators, who would make decisions about funding for higher education.

The message for all these effortsfrom the business plan to the research to the advertising and media relations-was relatively simple: funding UK's goal of becoming a Top 20 public research institution would help the university be a catalyst for creating a state that would be healthier, wealthier and wiser. At the end of the Kentucky legislative session,
UK received a historic increase in funding for a two-year period: $\$ 25$ million in new operating money for the next two years, almost "precisely what UK sought for the beginning of its serious climb to becoming a Top 20 public research university. Add to that almost all of the $\$ 80$ million in capital funds still needed to start work on a $\$ 120$ million building for the nation's No. 8 pharmacy school and UK had its biggest dreams fulfilled" (Jester, 2006, p. A1).

Todd later said that when people were asked about the business plan or talked about it, they would probably talk in terms of accountability-the idea that the university was asking for a certain level of support, but in return would measure its progress and report back. More unspoken in the plan itself, but deeply embedded throughout it, Todd said, was the idea of an engaged university in service to the entire Commonwealth of Kentucky (Todd, 2007, personal communication, 14 March).

The University of Kentucky's approach to asking for increased public support, however, is hardly an isolated one. In an era when public universities face increasing challengescompeting with each other for students and with other public entities for state appropriations-more institutions of higher learning are turning to advertising, marketing, and public relations techniques to articulate their agenda and push for support.

Increasingly, that message-and the way the university "brands" itself in the public domain-centers on university engagement efforts.

Against that backdrop, the purpose of this article is to examine public engagement as a branding and public 
relations strategy at colleges and universities. First, I briefly discuss the challenging budgetary and political landscape that has led public universities to pursue engagement as a means of increasing public support. Second, I describe some of the conditions that must be met to create a successful environment for engagement. Specifically, this paper posits the idea that engagement efforts require a focused and, if possible, centralized approach on the part of colleges and universities. Finally, I argue that successful branding and marketing of engagement efforts require a similar approach-an alignment, if not centralization, of resources within the campus, led by the institution's president and focused on an integrated strategic message that is backed by research. As a result, this paper-through a case study of one large public university's efforts to brand engagement-suggests that successful branding and engagement are inter-related and, to a large, degree interdependent.

\section{The Budgetary Landscape- The Waxing and Waning of Support}

Higher education historian John Thelin cautions that laments about lacking state support-which, in most cases, provides a large percentage of the annual operating dollars that drive public universities-can be misleading. His point is that, while significant challenges emerge for public and private higher education, both their overall budgets and their visions of what they want to accomplish continue to grow (Thelin, 2004).
Nevertheless, mounting evidence exists that there is an increasing strain in the relationships between public universities and the states on which they rely for so much of their funding. That strain makes the stakes for close relationships with state government and a university committed to public service and engagement even more important and crucial. "State governments and public colleges and universities have a symbiotic relationship,” David J. Weerts and Justin M. Ronca write in a recent article examining state appropriations to Research Universities in the 1990s. "Still, there is widespread evidence that the state-university relationship is eroding, as seen by the decline in appropriations for higher education during the past two and a half decades" (Weerts and Ronca, 2006, p. 935). The authors cite research by Mortenson (2004) suggesting that state investment for public higher education per personal income has dropped $\$ 32.1$ billion below that of 1980 . And William Zumeta writes that funding for public higher education on the state level has fallen steadily as a percentage of personal income for more than 20 years nationally (Zumeta, 2004).

\section{A Call for Engagement}

Clearly, one response to this challenging budgetary climate has been a renewed focus on the part of colleges and universities toward engagement efforts. For the purposes of this article, engagement is understood broadly. It is the idea that universities-through their engagement and outreach efforts-can, with the appropriate resources and support, help solve the 
challenges confronting the states and regions they serve. As Phil Greasley, the associate vice president for university engagement at the University of Kentucky put it, “don't give us money so we can be a great ivory tower university." The idea is to tell legislators and the public at large: "Give us more money so we can advance Kentucky” (Greasley, 2007, personal communication, 16 March).

To that end, in December 2005, the University of Kentucky unveiled its Top 20 Business Plan-the financial document that university officials said outlined the resources and commitment necessary to transform UK into a top-tier public research institution by 2020. Although largely a financial blueprint, the pages of the business plan make numerous references to the idea of linking UK's rankings push with progress for Kentucky. A "compact" between Kentucky and its flagship institution of higher learning, the plan contends, is "essential to any effort to make every Kentucky community stronger and the life of every Kentuckian better in a knowledge economy" (UK Top 20 Business Plan, 2005, Executive Summary). To underscore its importance, the business plan draws an increasingly used correlation in public higher education-a university's fiscal health (through funding) is equivalent to that of the region or state it services. UK's business plan, for example, cites the fact that, on average, states with so-called Top 20 institutions had higher household incomes, lower unemployment rates and healthier children than the national average. To get there, Todd and UK officials are calling for the university's budget to grow by more than $\$ 1$ billion between now and 2020 to hire 625 new faculty members, increase research output by more than $\$ 300$ million annually and add about 7,000 students (Fain, 2006).

Not surprisingly, though, the University of Kentucky is not an island, alone, making a push for national prominence. Nor is it alone in citing the connection between university growth and state economic advancement and prosperity. Arizona State University President Michael Crow is boldly touting his institution as an "New American University," aggressively pushing a 10 -year plan to "abandon the ivory-tower model of higher education that has shaped many American colleges ... to transform Arizona State into a university embedded in its community, one that will serve as a powerful force for social, cultural, economic, and environmental progress throughout the state" (Pulley, 2005, p. 1).

And the University of Minnesota recently announced plans to be ranked "among the top three public research universities in the world within the next decade." Its plan to get there, aptly enough, is titled "Advancing the Public Good: Transforming the U.” The idea, according to University of Minnesota Provost Tom Sullivan, is to “emphasize the 'public' because, as a public university, we have a special mission to advance the public good ... It's all about returning to the community ... the products of our best discoveries in teaching and research" (UMN News, 2005).

In short, these universities are talking about leveraging engagement efforts for increased state support. At the University of Kentucky, Greasley, the associate vice president for 
university engagement, said the Top 20 Business Plan-along with the institution's most recent strategic plan-have served as a catalyst for formalizing approaches to engagement on campus. There always have been very strong service components at the institution-experiential education programs; the university's medical center; its College of Medicine, which alone, has some 1,200 contracts for providing healthcare; and the cooperative extension service, which has at least one agent in each of the state's 120 counties. Until recently, however, there has not been a comprehensive effort to systematically catalog those efforts or to get a handle on structurally how the university has been approaching outreach and engagement. To advance its effort, Greasley said the university is surveying all engagement activities in colleges and departments throughout the institution. Last year, the effort started with a pilot project of three colleges. Now, the initiative is being expanded university-wide. One result, Greasley said, will be an interactive, online map that will allow legislators or other vested publics to click on a specific county and see every project the university has in that area or district (Greasley, 2007, personal communication, 16 March).

On a more global level at the university, since Todd assumed the presidency in 2001, there has been a slow, but unmistakable process of centralizing major administrative functions-a key factor both in engagement and communications efforts. Todd immediately instituted a provost structure, which centralized all academic units under one administrative head. Previously, academic units reported to a chancellor for the main campus; health sciences, the university hospital and medical center reported to another chancellor. Other departments, such as public relations, parking, security and business functions, which previously had operated separately on the main and medical campuses, were consolidated (Todd, 2007, personal communication, 14 March).

\section{Branding Engagement}

Long a staple of marketing in the commercial marketplace, "marketing has often been considered a taboo topic in higher education." Higher education has not traditionally talked about or conceptualized students as customers or consumers (Toma et al., 2005 , p. XI). Nor, it might reasonably be assumed, has public higher education considered other vested publics-such as communities or legislators, for that matter-as stakeholders and customers who need and deserve customized attention and service. But such an approach, Toma and his colleagues write, can be used by higher education constructively to ensure that institutions are meeting their established missions.

To that end, "branding" an institution in accordance with its cultural values and norms can help a university differentiate itself in an already crowded and competitive marketplace, whether that competition is for students, donors or public support. The idea, more specifically, is "exploiting" the perception that having a successful university demonstrates that a community is successful as well. Or, put another way, the goal is to prompt individuals "to use the 
attribute they believe defines the institution to also define themselves" (Toma et al., 2005, p. 16).

Brands are how consumers in the marketplace differentiate products. The goal is to have that brand build up a high degree of "equity" or value, based on brand loyalty, awareness, perceived quality and brand association (Toma et al., 2005). Petromilli, Morrison and Million write that branding is all the expectations and associations "evoked from experiences with a company or its offerings ... the actual brand is how customers think and feel about what the business, product or service does" (Petromilli et al., 2002, p. 2). For universities, influencing that relationship-whether between institution and prospective student or with public policy-maker-is difficult in a marketplace crowded with 3,600 colleges and universities (McDonald, 2006) and competing funding needs.

Fisher and Schultz separately argue for a sense of integration, although Schultz cautions that integrating units and departments-much less messages at a highly decentralized university-is difficult, if not impossible. He argues instead for "alignment," in which unified messages are presented from the institution and its many units. There are simply "too many functional and administrative silos in higher education to ever be integrated" (Schultz, 2006, p. 3). Nevertheless, Fisher suggests that the primary purpose of integration-or to use Schultz's term, alignment-is to "provide clarity around a single idea," which helps "achieve the organization's strategic objectives by enhancing reputation in the chosen area" (Fisher, 2006 , p. 8). For example, he points out that certain products or brands in the marketplace conjure specific images in the minds of consumers-Volvo equals safety. IBM connotes solutions and Apple carries with it the value of creativity. Schultz argues that such an integrated brand management process is designed, then, to "build ongoing relationships with customers and consumers," creating "the emotional ties," that the customers believes is with something of value or importance (Schultz, 2003, p. XIX).

Most prominently, higher education's branding efforts have revolved around athletics and, more specifically, collegiate football. Toma writes that football has allowed many universities to distinguish themselves in ways that their academic programs have not allowed. Football, in general, at the turn of the twentieth century helped raise the institutional profile of higher education, increasing support in what already was a highly decentralized environment (Toma, 2003). The idea, of course, is that people are always more likely to support an institution or product that they can have some level of identification with or loyalty to a brand. Advancing that brand could be, and often is, a key to stronger external relations (Toma, 2003). Notre Dame, the Catholic university near the industrial town of South Bend, Ind., may be the most prominent example of leveraging an athletic brand for wider institutional missions and purposes. Notre Dame, Toma argues, was able to use its success on the football field in the early twentieth century under the coaching of Knute Rockne and then others, to build a national identity and brand. That was leveraged later to build its brand as an 
academic institution of national importance (Toma, 2003).

Terry Flannery, assistant vice president of university marketing communications at the University of Maryland, said branding is not-and should not be-simply admissions related. Maryland began more institutional marketing or branding efforts about 10 years ago. Four brand values-quality, discovery, impact and momentum-were developed. The impact piece, Flannery says, was the idea of communicating with people the benefits of a research university. As the institution did a situational analysis and strategic plan, "the sort of traditional view of research institutions emerged" that research was something being done "at the expense of undergraduate education" (Flannery, 2007, personal communication, 27 March). Discovering that, and then creating a brand and communications strategy to confront that challenge, required research, Flannery says. As such, it was foundational to all the efforts going forward. "We wouldn't have been able to strategically select areas of strength or things we need to work on to cultivate awareness, support or loyalty. If we hadn't identified the fact that people found research and undergraduate support mutually exclusive, we wouldn't have known the depth of the issue that we needed to address" (Flannery, 2007, personal communication, 27 March).

And, as with engagement, Sickler notes that in branding and marketing an institution, no matter what the message, a senior-level administrative commitment to the goals and strategies is critically important (Sickler, 2006). After all, as Sickler notes, "living the promise is often the real marketing challenge" (Sickler, 2006, p. 38). A commitment, therefore, from the highest levels of the institution is vital. Toma and Sevier echo the necessity of top-level commitment to branding. "It's essential," Toma said in an interview about buy-in for branding at the top levels of administration. "At the level of institutional vision, that's what presidents are supposed to do. That's what they are there to remind us of. If they're screwing around with the details, they are probably not doing their job" (Toma, 2007, personal communication, 20 March; Sevier, 2007, personal communication, 28 February).

Another important element is integration of staffing to the extent possible. Flannery notes that media relations, publications and marketing at the University of Maryland is integrated-about 30 people who work for her-although she notes that there are another 50 or 60 people involved in communications-related functions in colleges and departments across her campus. Nevertheless, integration of functions and staffing allows "us to bring to all of those capabilities together." In addition, her areas work closely with federal and state relations departments to develop unified communications on behalf of the institution. Engagement activities are housed separately in the College of Agriculture and Natural Resources, where the university's extension function has traditionally been located. It would be unrealistic, she says, to assume that a "one-stop" shop could be created for engagement, given all the people who interact with the university. Yet, her area and engagement work closely together, again to help ensure unified messaging 
(Flannery, 2007, personal communication, $27 \mathrm{March})$. And Toma argues that universities should "centralize to the extent that you can in a public affairs shop. Don't let the people at the unit level do their own branding or their own activities toward branding. You've got to have a coherent message. It's got to be a subtle message" (Toma, 2007, personal communication, $20 \mathrm{March})$.

\section{The University of Kentucky as an Engagement Branding Case Study}

A similar framework and strategic planning process played out for the University of Kentucky as it prepared its Top 20 Business Plan and for a critical state legislative session. As with the University of Maryland, focus group and survey research conducted in late 2004 indicated that there was virtually no connection in the eyes of the public between having a Top 20 public research institution and improving the state. Particularly distressing was the fact that people surveyed and talked to did not connect the relevance of university-based research in changing the state for the better (Cornett Integrated Marketing Services, 2005). That foundation of research proved vital, says Tom Harris, UK's associate vice president for external relations. "The research outlined to the university administration the long road we had to travel to communicate our message and the resources that would be required to start that process. The research was the basis for our entire message strategy going into the Top 20 campaign" (Harris, 2007, personal communication, 6 April).
Most importantly, Harris said, the research demonstrated that the university had "not told the story" about its impact on the state, whether in the form of extension offices in every county or the provision of healthcare throughout much of Eastern Kentucky, the state's poorest region. "Our challenge became evident-tell simple stories of how the University of Kentucky makes lives better in the Commonwealth and makes research real to its people" (Harris, 2007, personal communication, 6 April). Another key decision, according to Harris, was that research and communications focused primarily on a somewhat limited audience and demographic. Statewide survey research that was conducted in late 2004-and subsequent focus groups in 2005-concentrated on community opinion leaders, people with household incomes above $\$ 60,000$ annually and alumni. The strategic decision, Harris said, was made, in part, because of finite resources and in part because selling the Top 20 plan in the short run meant convincing legislators to make an initial funding investment. "We needed to educate (and) energize those individuals that watch the nightly news and public issues shows like Face The Nation” (Harris, 2007, personal communication, 6 April).

The university's external relations area, including public relations and marketing, underwent a strategic planning process. The goal was to create a brand position that would guide all communications effortsmedia relations, advertising and marketing-leading into and through the 2006 legislative session. Utilizing the research conducted, UK's external relations adopted a brand position 
statement of "UK: Catalyst for a new Commonwealth." The inherent idea was that funding and supporting UK was a way to increase educational attainment levels, foster economic growth and development, and improve healthcare. The strategy manifested itself in a number of ways, from the seemingly small to the large in scale. All news releases, for example, contain boilerplate language at the end, discussing the university's commitment to being a Top 20 institution as a way of being a "catalyst" for improving Kentucky. On a more grand scale, Todd kicked off-and participated in-a nine-day, 22-city "Dream Tour," modeled after UK's institutional tagline of "Dream. Challenge. Succeed." Todd, deans and other academic representatives toured the state in a greyhound-style bus, wrapped in color photos of smiling students. At each stop, Todd would meet with legislators, schoolchildren, alumni and media. Harris said print advertising and some limited radio was planned to accompany the tour, touting the impact of the university's outreach efforts throughout Kentucky. "There was a wake of excitement and a much greater understanding of the University of Kentucky's role in the Commonwealth and our quest for Top 20 left in every community we visited. They absolutely knew we had been in town" (Harris, 2007, personal communication, 6 April).

For example, in one day in the state's largest city, Louisville, Todd started interviews at $4 \mathrm{am}$ and ended with a dinner for alumni at $7 \mathrm{pm}$. In between were ten media interviews, a breakfast meeting and lunch with opinion leaders. The impact of the tour on the institution's efforts to create a connection between research and the state's growth was profound, according to Todd. "It showed we were willing to get out of Lexington and go around this state and spend quality time (with people) ... Part of what the trip was all about was to go out and tell people how much research we did and tell them about the quality of the faculty we have and just sell the university to people" (Todd, 2007, personal communication, 14 March). A key element of that was more directly talking about some of the institution's engagement efforts.

On the tour, Todd unveiled what he dubbed the "Commonwealth Collaboratives" -23 research projects in which central administration invested $\$ 10,000$ each as seed money that directly tied to pressing challenges or problems confronting Kentucky. Todd had long referred to such intractable issues as the "Kentucky Uglies," insidious diseases such as lung and colorectal cancer, cardiovascular disease and tooth decay in which Kentucky leads the nation. Greasley says that the Commonwealth Collaboratives, specifically, are projects done with communities where the problems are significant and attack areas of priority need. From working with pre-term, low-weight babies to replanting efforts to mitigate the environmental impacts of mining or integrating the institution's efforts to stimulate its equine industry, each collaborative was designed to address specific areas of concern in Kentucky. Much of the "Dream Tour" was spent highlighting those efforts (Commonwealth Collaboratives website, http://www.uky.edu/UE/CC/ index.htm). 
Then as the Business Plan itself was finalized, a strategic decision was made to give it exclusively to the Lexington Herald-Leader, which ran a prominent front-page article, jumping to almost a full inside page. The glowing story touted the plan's impact on economic development and quoted legislative and higher education leaders in support of it conceptually (Blackford, 2005). An editorial shortly after the story appeared simply proclaimed "Fund UK's Top 20 Plan or Back Off" (Lexington Herald-Leader Editorial, 2005).

Finally, during the legislative session itself, a series of three television ads ran on selected statewide television markets. Instead of traditional institutional ads, featuring students on bucolic campuses or professors huddled over microscopes, each of the ads focused on the university's commitment to Kentucky. One featured mobile dental units that traverse the state and focus on oral care for children. Another ad emphasized a \$22 million grant the institution had received to motivate curriculum changes in secondary schools in Eastern Kentucky to focus more on math and science. And, a final ad promoted research that was improving economic development across Kentucky. Finally, the institution fully engaged an effort that had been building for about a year-the creation of grassroots organization, called UKAN (UK Advocacy Network). Each member of the organization has specific relationships with key legislators in their home counties or districts. At key points throughout the legislative session, they would be asked to deliver specific messages of support to elected officials they knew personally. During the 2006 session, those messages almost invariably centered on funding the Top 20 Business Plan.

The cumulative effect of the promotional campaign and branding engagement efforts were instrumental in the subsequent legislative success enjoyed by UK, says Steve Byars, the university's director of governmental relations. "It provided the air cover, the air support (we needed during the session)" (Byars, 2007, personal communication, 2 April). How did the success happen and how does the institution structure and frame its efforts going forward? These are important questions to consider, given that engagement branding efforts were focused on a targeted audience for a limited purpose-funding in one legislative session.

First, Bill Swinford, UK's director of policy and planning, agrees with others involved in both engagement and branding efforts that structure is important. UK's external relations areas-public relations, government relations, the campus radio stationsall are organized in the same department. Alumni relations and development are closely related units as well. As a result, conversations and strategies can occur quickly without concerns about turf (Swinford, 2007, personal communication, 2 April).

Second, even though the funding tied to the collaboratives involved a relatively small amount, Greasley said incentivizing engagement efforts is critical. The institution is now planning a second round of funding for collaboratives in which 12 will be announced, one at a time, once a month. Moreover, the research is done with a high level of community 
involvement and collaboration. Efforts in the future will include focus groups across the state with community stakeholders to better gauge needs and areas for collaboration and partnership. In addition, Greasley says, the institution will conduct, for the second year, a statewide conference on engagement. UK also is looking into ways to incentivize engagement activities at the faculty level, perhaps by creating a title position of "Public Scholar" or to create an engagement academy where young professors can learn to include engagement in their research efforts in a way that doesn't diminish, but instead complements, tenure and departmental goals (Greasley, 2007, personal communication, 16 March).

For his part, Todd sees the most recent legislative session, and the campaign that helped drive UK's success, as part of future positioning of the institution. It is important, he argues, to continue the conversation, to "drive this home in the minds of Kentuckians" about how UK is a catalyst for progress in the state. $\mathrm{He}$ characterizes it as an ongoing conversation with people, fueled by specific programs attacking challenges and needs confronting Kentucky. It started with efforts years ago, when he first became president, to convince people on campus that the effort was worthwhile. Banners sprung up on campus, touting the accomplishments of faculty, alumni and students. Landscaping improvements were made to create a sense of pride. During timeouts at football and basketball games, Todd would introduce academic and research luminaries, touting their work as connected to state improvements. All of it was tied to convincing both internal and external audiences that Top 20 was possible and it was, and is, important to the state.

In short, he was trying to create a brand identity for UK, focused on its role in making the state a better place. An engaged university, he argues, is central to that effort (Todd, 2007, personal communication, 14 March).

\section{The Balancing Act of Engagement and Branding}

The challenge for public institutions today is how to ensure that such efforts-both engagement and branding-are focused, centralized and collaborative. As Toma and others would argue, a culture that encourages those values, and then incentivizes what Weerts and Sandmann (2006) would characterize as a "two-way street" approach to engagement can build a new paradigm of brand equity for public universities, based on their engagement and outreach to the communities and states they serve. There is powerful evidence, still anecdotal at this point, to suggest that such brand identification, awareness and equity, can enhance public funding and institutional support.

But for public higher education, such a strategy is a delicate balancing act. On campus, the institution's culture must not only recognize, but incentivize, engagement efforts. In addition, such engagement efforts must be accountable to-and be established in partnership with-the very publics they are designed to serve. Finally, as institutions seek to brand those efforts through an integrated strategic marketing and communications strategy, it is critical that perception 
and marketing does not outpace the reality of engagement. Legislators and the public, in general, expect more of universities in terms of service, outreach, and the results they get for the dollars they are willing to invest in such efforts. In other words, public higher education-whether in a push for student rankings or in an outreach effort outside the campus bordersmust demonstrate that public engagement is as much reality as it is rhetoric.

\section{Acknowledgements}

To Carla Blanton for her enduring support and "Coach" John Thelin for his willingness to mentor.

\section{References}

Blackford, L.B. (2005), "Rally round the flagship: Lee Todd says his bold plan for UK will do great things for the state, too," Lexington Herald-Leader, 5 December, p. A1.

Commonwealth Collaboratives website, Available online: http://www.uky.edu/UE/CC/index.htm University of Kentucky (2006-2007).

Editorial (2005), “Back UK's Top 20 plan or back off," Lexington Herald-Leader, December.

Fain, P. (2006), "Big dreams in the bluegrass state: The University of Kentucky's president seeks to make his state's flagship university a top-20 public research institution," The Chronicle of Higher Education, 28 April, p. 1.

Fisher, R. (2006), "Building university brands that matter Presentation at Stamats Strategic Integrated Marketing Conference," July 2006, p. 8, Chicago, IL.

Jester, A. (2006), "UK asks and it shall receive: President Todd gets nearly everything on budget wish list," Lexington Herald-Leader, 15 April, p. A1.

McDonald, F. (2006), "Cutting through the clutter: Creating messages that get noticed Presentation at Stamats Integrated Marketing Conference," July 26, 2006, p. 4, Chicago, IL.

Mortenson, T. (2004, January), Postsecondary Education OPPORTUNITY, 139, Mortenson Research Seminar on Public Policy Analysis of Opportunity for Postsecondary Education, Oskaloosa, IA.
Petromilli, M., Morrison, D and Million, M. (2002), "Brand architecture: Building brand portfolio value," Strategy and Leadership, 30,5, p. 2.

Pulley, J. (2005), "Raising Arizona: Is Michael Crow's remaking of state university a model, or a mirage," The Chronicle of Higher Education, 18 November, p. 1.

Schultz, D.E. (2003), "Evolving marketing and marketing communication into the twenty-first century," in D. Iacobucci and B. Calder (eds.), Kellogg on Integrated Marketing, Northwestern University, John Wiley \& Sons, Inc., Hoboken, New Jersey.

Schultz, D.E. (2006), "The future of integrated marketing in higher education Stamats Integrated Strategic Marketing Conference,” July. Chicago, IL

Sickler, E. (2006), “Maximizing the return on your institutional marketing investment Stamats Integrated Strategic Marketing Conference," July 26, p. 38. Chicago, IL

Thelin, J. (2004), A History of American Higher Education, Johns Hopkins University Press, Baltimore, MD.

Toma, J.D. (2003), Football U.: Spectator Sports in the Life of the American University, The University of Michigan Press, Ann Arbor, MI.

Toma, J.D, Dubrow, G. and Hartley, M. (2005), "The uses of institutional culture strengthening identification and building brand equity in higher education," ASHE Higher Education Report.

University of Kentucky Marketing Campaign, Focus Group Report, Research Conducted on Behalf of Cornett Integrated Marketing Services, (2005).

University of Kentucky (2005), “Top 20 Business Plan," Executive Summary.

University of Minnesota (2005), UMN News, Available online: http://www1.umn.edu/ umnnews/Feature_Stories/Among_the_best_in_ the_world.html.

Weerts, D.J. and Ronca, J.M. (2006), "Examining differences in state support for higher education: A comparative study of state appropriations for research universities," Journal of Higher Education, 77, 6, pp. 935-965.

Weerts, D.J. and Sandmann, L.R. (November 2, 2006), "Building a two-way street: Toward a theory of knowledge flow in universitycommunity partnerships," Conference paper presented at the Association for the Study of Higher Education, Anaheim, California.

Zumeta, W. (2004), "State Higher Education Financing: Demand Imperatives Meet Structural, Cyclical and Political Constraints," in E. P. St. John and M. D. Parsons (eds.), Public Funding of Higher Education: Changing Contexts and New Rationales, Johns Hopkins University Press, Baltimore, MD. 